\title{
WEIGHTED OSTROWSKI, TRAPEZOID AND GRÜSS TYPE INEQUALITIES ON TIME SCALES
}

\author{
WENJUN LiU AND ADNAN TUNA
}

Abstract. In this paper we first derive a weighted Montgomery identity on time scales and then establish weighted Ostrowski, trapezoid and Grüss type inequalities on time scales, respectively. These results not only provide a generalization of the known results, but also give some other interesting inequalities on time scales as special cases.

Mathematics subject classification (2010): Primary 26D15, 26E70.

Keywords and phrases: Montgomery identity, Ostrowski inequality, trapezoid inequality, Grüss inequality, time scales.

\section{REFERENCES}

[1] R. Agarwal, M. Bohner And A. Peterson, Inequalities on time scales: a survey, Math. Inequal. Appl. 4, 4 (2001), 535-557.

[2] F. M. Atici, D. C. Biles And A. Lebedinsky, An application of time scales to economics, Math. Comput. Modelling 43, 7-8 (2006), 718-726.

[3] M. Bohner, M. FAn And J. M. Zhang, Periodicity of scalar dynamic equations and applications to population models, J. Math. Anal. Appl. 330 (2007), 1-9.

[4] M. Bohner And A. Peterson, Dynamic equations on time scales, Birkhäuser Boston, Boston, MA, 2001.

[5] M. Bohner And A. Peterson, Advances in dynamic equations on time scales, Birkhäuser Boston, Boston, MA, 2003.

[6] M. Bohner And T. Matthews, The Grüss inequality on time scales, Commun. Math. Anal. 3, 1 (2007), 1-8 (electronic).

[7] M. Bohner And T. Matthews, Ostrowski inequalities on time scales, JIPAM. J. Inequal. Pure Appl. Math. 9, 1 (2008), Article 6, 8 pp.

[8] M. Bohner, T. Matthews And A. Tuna, Diamond- $\alpha$ Grüss type inequalities on time scales, Int. J. Dyn. Syst. Differ. Equ. 3, 1/2 (2011), 234-247.

[9] P. Cerone, S. S. Dragomir and J. Roumeliotis, An inequality of Ostrowski type for mappings whose second derivatives are bounded and applications, RGMIA Research Report Collection 1 (1998), 33-39.

[10] P. CERONE AND S. S. DRAGOMIR, Midpoint-type rules from an inequalities point of view, in Handbook of analytic-computational methods in applied mathematics, 135-200, Chapman \& Hall/CRC, Boca Raton, FL.

[11] C. Dinu, Ostrowski type inequalities on time scales, An. Univ. Craiova Ser. Mat. Inform. 34 (2007), $43-58$.

[12] S. HILGER, Ein Maßkettenkalkül mit Anwendung auf Zentrumsmannigfaltigkeiten, Ph.D. thesis, Universität Würzburg, Würzburg, Germany, 1988.

[13] B. KARPUZ AND U. M. ÖZKAN, Generalized Ostrowski's inequality on time scales, JIPAM. J. Inequal. Pure Appl. Math. 9, 4 (2008), Article 112, 7 pp.

[14] V. Lakshmikantham, S. Sivasundaram and B. Kaymakcalan, Dynamic systems on measure chains, Kluwer Acad. Publ., Dordrecht, 1996.

[15] G. LaPenta, Particle simulations of space weather, J. Comput. Phys. 231, 3 (2012), 795-821. 
[16] W. N. LI, Some delay integral inequalities on time scales, Comput. Math. Appl. 59, 6 (2010), 19291936.

[17] W. N. Li AND W. H. Sheng, Some Gronwall type inequalities on time scales, J. Math. Inequal. 4, 1 (2010), 67-76.

[18] W. J. LiU, Some weighted integral inequalities with a parameter and applications, Acta Appl. Math. 109, 2 (2010), 389-400.

[19] W. J. LiU AND Q.-A. NGô, An Ostrowski-Grüss type inequality on time scales, Comput. Math. Appl. 58, 6 (2009), 1207-1210.

[20] W. J. LiU AND Q.-A. NGô, A generalization of Ostrowski inequality on time scales for $k$ points, Appl. Math. Comput. 203, 2 (2008), 754-760.

[21] W. J. LIU, Q.-A. NGô AND W. B. CHEN, A perturbed Ostrowski-type inequality on time scales for $k$ points for functions whose second derivatives are bounded, J. Inequal. Appl. 2008, Art. ID 597241, $12 \mathrm{pp}$.

[22] W. J. LiU, Q.-A. NGÔ AND W. B. Chen, Ostrowski type inequalities on time scales for double integrals, Acta Appl. Math. 110, 1 (2010), 477-497.

[23] W. J. LIU, Q.-A. NGÔ AND W. B. CHEN, A new generalization of Ostrowski type inequality on time scales, An. Ştiinţ. Univ. "Ovidius” Constanţa Ser. Mat. 17, 2 (2009), 101-114.

[24] D. S. Mitrinović, J. E. PeČArić AND A. M. FinK, Inequalities involving functions and their integrals and derivatives, Kluwer Acad. Publ., Dordrecht, 1991.

[25] Q.-A. NGÔ AND W. J. LiU, A sharp Grüss type inequality on time scales and application to the sharp Ostrowski-Grüss inequality, Commun. Math. Anal. 6, 2 (2009), 33-41.

[26] A. Ostrowski, Über die Absolutabweichung einer differentiierbaren Funktion von ihrem Integralmittelwert, Comment. Math. Helv. 10, 1 (1937), 226-227.

[27] B. G. PachPatte, On trapezoid and Grüss-like integral inequalities, Tamkang J. Math. 34, 4 (2003), 365-369.

[28] M. Z. SARIKaYA, A note on Grüss type inequalities on time scales, Dynam. Systems Appl. 17, 3-4 (2008), 663-666.

[29] M. Z. SARIKAYA, N. AKTAN AND H. YILDIRIM, On weighted Čebyšev-Grüss type inequalities on time scales, J. Math. Inequal. 2, 2 (2008), 185-195.

[30] M. R. Sidi Ammi And D. F. M. Torres, Combined dynamic Grüss inequalities on time scales, Journal of Mathematical Sciences 161, 6 (2009), 792-802.

[31] C. Soria-Hoyo, F. Pontiga and A. Castellanos, A PIC based procedure for the integration of multiple time scale problems in gas discharge physics, J. Comput. Phys. 228 (2009), 1017-1029.

[32] H. M. SRivastava, K.-L. Tseng, S.-J. Tseng And J.-C. Lo, Some weighted Opial-type inequalities on time scales, Taiwanese J. Math. 14, 1 (2010), 107-122.

[33] K.-L. Tseng, G.-S. YAng And S. S. Dragomir, Generalizations of weighted trapezoidal inequality for mappings of bounded variation and their applications, Math. Comput. Modelling 40, 1-2 (2004), 77-84.

[34] K.-L. Tseng, S. R. Hwang And S. S. Dragomin, Generalizations of weighted Ostrowski type inequalities for mappings of bounded variation and their applications, Comput. Math. Appl. 55, 8 (2008), 1785-1793.

[35] A. Tuna And D. Daghan, Generalization of Ostrowski and Ostrowski-Grüss type inequalities on time scales, Comput. Math. Appl. 60, 3 (2010), 803-811.

[36] A. Tuna, Y. Jiang And W. J. LiU, Weighted Ostrowski, Ostrowski-Grüss and OstrowskiČebyhev Type Inequalities on Time Scales, Publ. Math. Debrecen 80 (2012), to appear.

[37] S. F. WANG, Q. L. Xue, W. J. LiU, Further generalization of Ostrowski-Grüss type inequalities, Adv. Appl. Math. Anal. 3, 1 (2008), 17-20.

[38] C.-C. YeH, Ostrowski's inequality on time scales, Appl. Math. Lett. 21, 4 (2008), 404-409. 